\title{
DEMOSTRACION DEL VIRUS DE LA ENCEFALITIS EQUINA VENEZOLANA TIPO ENZOOTICO EN LA HEMOLINFA DE MOSQUITOS PSOROPHORA CONFINNIS INFECTADOS POR VIA ORAL
}

\author{
ALBERTO MORALES, * MARGARITA ROMERO, ** VICTOR ALBERTO OLANO, *** \\ DORA DE CALVACHE. ****
}

\begin{abstract}
Se llevó a cabo un experimento con el propósito de determinar si en mosquitos Psorophora confinnis (Arribalzaga, 1.891) infectados por vía oral con una cepa enzoótica de Encefalitis Equina Venezolana era posible detectar el virus en la hemolinfa de estos mosquitos.

El virus se pudo demostrar en la hemolinfa a las 24 horas postinfección en el $66,6 \%$ de los mosquitos, en el $75 \%$ de los mosquitos a los 2 y 9 días post-infección y en el $100 \%$ de los mosquitos a los 6-7-8-10-11-12 y 13 día post-infección.
\end{abstract}

Todos los mosquitos en los cuales se demostró virus en la hemolinfa fueron probados para intento de aislamiento de virus en el mosquito total y hubo una perfecta correlación entre los dos. Los mosquitos que fueron negativos para virus en la hemolinfa también lo fueron cuando se probaron como mosquito total. En algunas hembras tomadas al azar se hizo una comparación de los títulos del virus en la hemolinfa y en el mosquito total y no se encontró una diferencia significativa.

\section{INTRODUCCION}

En un trabajo anterior Morales y col.(1) demostraron que el virus Dengue 2 podía ser detectado en la hemolinfa circulante de mosquitos Aedes aegypti que habían sido previamente inoculados con este virus por vía intratorácica; en una alta proporción de los mosquitos inoculados se pudo demos- trar el virus en la hemolinfa durante varios días post-inoculación.

Los anteriores resultados indujeron a pensar que podría ocurrir el mismo fenómeno en mosquitos infectados por vía oral con otros arbovirus, es decir, que una vez que las particulas virales ingeridas por el mosquito se repliquen en las células de la

\footnotetext{
* Bacteriólogo, M.Sc. Grupo de Entomología, Instituto Nacional de Salud (INS). Apartado 80334. Bogotá, Colombia, S.A.

** Bacterióloga. Grupo de Virología (INS).

*** Biólogo. Grupo de Entomología (INS).

**** Bacterióloga. Grupo de Virología (INS).
} 
pared del estómago del insecto, y la atraviesan, empezarían a circular en la hemolinfa y por esta vía alcanzarían los diferentes tejidos del insecto y se podrían demostrar en el fluído varios días después de la infección del mosquito, quizás durante toda la vida del insecto.

La comprobación de este hecho con otros arbovirus, además de contribuir al mejor conocimiento de la evolución de estos virus en los artrópodos vectores, sería de gran utilidad pues permitiría detectar el virus en la hemolinfa y haría posible conservar el mosquito intacto para posteriores confirmaciones de su taxonomía y estudios virológicos adicionales. Por otra parte, es bien conocido el hecho de que cuando se recolectan mosquitos recién ingurgitados para intento de aislamiento de virus, se hace necesario permitir que estas hembras hagan la digestión de la sangre ingerida antes de procesarlas, lo cual tarda varios días; lo anterior se evita cuando a los mosquitos recién capturados se les examina la hemolinfa.

Por las razones expuestas anteriormente se decidió llevar a cabo un experimento para tratar de determinar si en mosquitos Psorophora confinnis infectados por vía oral con una cepa de virus de Encefalitis Equina Venezolana tipo enzoótico, las partículas virales se podrían detectar en la hemolinfa varios días después de que las hembras de Ps. confinnis hubieran hecho la comida infectante.

\section{MATERIALES Y METODOS}

\section{Mosquitos}

Los mosquitos usados procedían de una colonia de Psorophora confinnis (Arribalzaga, 1891) establecida inicialmente en el municipio de Armero, Tolima, Colombia en el año de 1978 y posteriormente adaptada al laboratorio en Bogotá. Los métodos de mantenimiento de esta colonia de mosquitos ya han sido descritos. (2).

Durante el curso del experimento se utilizaron hembras de 72 horas de edad, aunque en ocasiones fue necesario usar algunas de mayor edad.
Antes y después de la alimentación con la comida de sangre infectante, las hembras fueron mantenidas con una dieta de azúcar en agua al $10 \%$.

Los mosquitos se mantuvieron en jaulas metálicas Gerberg de 30 x $30 \mathrm{cms}$, en el laboratorio de seguridad de un insectario a prueba de escape de los insectos, a temperatura promedio de $27^{\circ} \mathrm{C}$ y humedad relativa aproximada de $72 \%$.

\section{Virus}

Para infectar los mosquitos se utilizó la cepa enzoótica de Encefalitis Equina Venezolana INS-V- 395, la cual se aisló el 28 de julio de 1970 a partir de un cerebro de hamster centinela expuesto en un bosque de la finca Riovista, en la vereda El Terminal, Municipio de Puerto Boyacá, Colombia y conservada liofilizada a $-70^{\circ} \mathrm{C}$. Esta cepa fue clasificada como perteneciente al subgrupo antigénico ID en los laboratorios Middle America Research Unit of Panamá. (MARU).

\section{Infección de los Mosquitos}

Como fuente de virus para los mosquitos se utilizaron 2 hamster virémicos.

En un primer experimento se usó un hamster virémico para alimentar a los mosquitos a los cuales se les iba a tomar hemolinfa hasta los 9 días post-alimentación; para infectar a este hamster, se le inoculó por vía subcutánea $0,03 \mathrm{ml}$. de la cepa enzoótica de EEV, INS-V-395, que contenía $\log 4,17$ DITC 50. (dosis que infectan el 50\% de los tubos con células). El título se calculó de acuerdo a la fórmula de Reed y Muench (3).

A las hembras de este primer experimento se les permitió alimentarse sobre el hamster virémico a las 48 horas después de que el animal había recibido el inóculo infectante. Para ello, el hamster se anestesió aplicándole por vía intraperitoneal una dosis de 0,04 mgrs de pentotal sódico por cada 10 gramos de peso del animal y una vez inmovilizado se colocó sobre la malla de la jaula que contenía un número indeterminado de 
hembras de Ps. confinnis, de manera que los mosquitos picaran a través de la malla; a los mosquitos se les permitió alimentarse hasta cuando terminó la acción del pentotal sódico en el hamster. (1-3 horas). Los mosquitos que se habían ingurgitado eran colocados en otra jaula y mantenidos en las mismas condiciones de humedad y temperatura que se explicaron anteriormente. Dos de estos mosquitos ingurgitados fueron congelados a $-70^{\circ}$, inmediatamente terminaron de alimentarse, con el propósito de realizar con ellos intento de aislamiento de virus y verificar que habían ingerido partículas virales.

Una vez que terminó la exposición del hamster a la picadura de los mosquitos, se le tomó una muestra de sangre con el fin de determinar el título de la viremia.

Para ello, se insertó una micropipeta en el ángulo posterior de uno de los ojos del animal, se giró la pipeta para romper los capilares y así obtener la muestra, se separó el suero y se congeló. La viremia se tituló en células (VERO) obteniéndose un título de log 7,5 DITC 50 en un volumen de $0,1 \mathrm{ml}$. de suero. En un segundo experimento se alimentaron, en otro hamster virémico, los mosquitos a los cuales se les iba a extraer hemolinfa entre los días 10 a 13 post-infección. Este hamster fue infectado por vía subcutánea con una dilución de la misma cepa de EEV enzoótica que se usó para infectar el primer hamster cuya concentración era de $\log 2,9$ DITC 50 en $0,03 \mathrm{ml}$. El título de la viremia de este segundo hamster, calculado en la sangre tomada inmediatamente después de alimentados los mosquitos, fue de $\log 6,5$ DITC 50 en $0.1 \mathrm{ml}$. de suero. En este segundo experimento también se separaron 2 mosquitos inmediatamente después de alimentados para comprobar si habían ingerido virus.

\section{Extracción de la Hemolinfa}

La técnica de extracción de la hemolinfa de los mosquitos ya fue descrita en un trabajo anterior. (1). De cada mosquito se extrajeron aproximadamente 0,30 microlitos de hemolinfa, la cual se diluyó en $0,3 \mathrm{ml}$. de Medio 199 con 2\% de suero fetal bovino; en esta forma la hemolinfa quedó diluída a $10^{-3}$.
Las diluciones de la hemolinfa se conservaron a $-70^{\circ} \mathrm{C}$. A las hembras que se ingurgitaron en los dos hamster virémicos, se les tomó hemolinfa a partir de las 24 horas después de que hicieron la comida infectante y hasta el día 13, (exceptuando los días 3, 4 y 5, cuando no se extrajo hemolinfa. La extracción de la hemolinfa se hizo a grupos distintos de mosquitos, cada día.

Una vez extraida la hemolinfa, los mosquitos se conservaron individualmente, congelados a $-70^{\circ} \mathrm{C}$, para posterior intento de aislamiento de virus en el mosquito total y titulación del mismo con el propósito de poder comparar el título del virus en la hemolinfa con el título del correspondiente mosquito total.

En algunos casos se hizo titulación de la hemolinfa, pero no en el correspondiente mosquito total y viceversa.

A todas las hemolinfas extraídas se les hizo intento de aislamiento de virus inoculando en células (VERO) $0,1 \mathrm{ml}$. de la dilución de la hemolinfa en Medio 199 y observando el efecto citopatogénico; al mismo tiempo se inocularon controles negativos. A varias de las hemolinfas que produjeron efecto citopatogénico en las células inoculadas, se les hizo titulación y se identificó el virus aislado en el 5,5\% de estas hemolinfas tomadas al azar. Para ello se realizó la prueba de fijación de complemento de acuerdo con la técnica de Clarck y Casals modificada por Sever(4) frente a líquido ascítico hiperinmune para EEV.

Para el intento de aislamiento del virus en el mosquito total, las hembras, que se habían conservado a $-70^{\circ} \mathrm{C}$, fueron descongeladas y a cada una se le agregó $1 \mathrm{ml}$. de Medio 199 adicionado de $2 \%$ de suero fetal bovino como diluyente, "Sonicadas" y centrifugadas en frío a $3.000 \mathrm{rpm}$. durante 20 minutos; se separó el sobrenadanete el cual fue inoculado en células (VERO) en la cantidad de $0,1 \mathrm{ml}$. para observar efecto citopatogénico. A 19 de los mosquitos que produjeron este efecto en las células inoculadas se les hizo titulación del virus y de éstos, a 2 mosquitos, se les hizo fijación de complemento para identificar el virus. 


\section{RESULTADOS}

Un total de 59 mosquitos que se ingurgitaron sobre hamster virémicos fueron probados para virus en la hemolinfa y/o en el mosquito total.

En el cuadro No. 1 se muestran los resultados del intento de aislamiento de virus en la hemolinfa y en el mosquito total, en relación con los días transcurridos entre el momento en que las hembras de Ps. confinnis se alimentaron en el hamster virémico y aquel en el cual se probaron para presencia de virus.

Los mosquitos que fueron probados para aislamiento de virus entre el $1^{\circ}$ y el $9^{\circ}$ días post-infección se habían ingurgitado en un hamster cuya viremia tenía un título de log 7,5 en $0,1 \mathrm{ml}$. de suero. A las 24 horas se pudo detectar virus en la hemolinfa de 2 de 3 hembras; en las 2 hembras con hemolinfa positiva también se demostró el virus en el mosquito total. La hembra negativa en hemolinfa también lo fue cuando se probó el mosquito total. A una tercera hembra, que fue positiva para virus en el mosquito total, no se le pudo comprobar virus en la hemolinfa pues ésta se contaminó con hongos.

En las hembras investigadas para presencia de virus a los 2 días postalimentación en el hamster vi rémico, hubo perfecta correlación entre el aislamiento de virus en la hemolinfa y en el mosquito total; de 4 mosquitos probados, 3 fueron positivos y 1 negativo.

Los mosquitos probados al $6^{\circ}$ y $7^{\circ}$ día post-infección por vía oral, fueron positivos para aislamiento de virus tanto en la hemolinfa como en el mosquito total. Los 6 mosquitos cuya hemolinfa se probó al $8^{\circ}$ día post-infección fueron todos positivos y de estas 6 hembras, en 5 se realizó intento de aislamiento de virus en el mosquito total y de todas ellas se recuperó el virus.

En el noveno día post-infección oral de los mosquitos se probó la hemolinfa de cuatro y 3 de ellos fueron positivos. Los 3 mosquitos positivos en hemolinfa fueron tambien positivos cuando se probó el mosquito total y aquel que fue negativo en hemolinfa, también lo fue en el mosquito total. En este noveno día también se probaron para intento de aislamiento de virus, con resultado positivo, otras 3 hembras como mosquito total, las cuales no se investigaron en hemolinfa.

A los 2 mosquitos, separados y congelados inmediatamente después de alimentarse en el hamster que sirvió para alimentar los mosquitos probados para virus entre el $1^{\circ} \mathrm{y}$ el $9^{\circ}$ día post-infección, se les hizo intento de aislamiento de virus y titulación en células (VERO) con resultado de $\log$ 5,5 DITC50 en $0.1 \mathrm{ml}$. para el primer mosquito y de $\log 4,5$ en $0,1 \mathrm{ml}$. para el segundo mosquito.

Los mosquitos probados para virus entre el $10^{\circ}$ y el $13^{\circ}$ día post-infección, fueron alimentados en un hamster cuya viremia tenía un título de log 6,5 DICT50 en 0,1 ml. de suero, en el momento en que terminaron de

\section{CUADRO № ।}

Resultado del intento de aislamiento de virus EEV (tipo enzoótico) en la hemolinfa y en el mosquito total de Ps confinnis infectados por via oral y probados por efecto citopatogénico con células VERO

\begin{tabular}{|c|c|c|}
\hline $\begin{array}{c}\text { Días post-alimen_- } \\
\text { mentación de los }\end{array}$ & \multicolumn{2}{|c|}{$\begin{array}{l}\text { Número de mosquitos probados in } \\
\text { dividualmente en células VERO }\end{array}$} \\
\cline { 2 - 3 } $\begin{array}{c}\text { mosquitos Ps. con } \\
\text { finnis en los hams }\end{array}$ & Hemolinfa & Mosquito total \\
\hline ter virémicos. & Positivo/total & Positivo/ total \\
\hline 1 & $2 / 3$ & $3 / 4$ \\
2 & $3 / 4$ & $3 / 4$ \\
6 & $4 / 4$ & $5 / 5$ \\
7 & $6 / 6$ & $6 / 6$ \\
8 & $6 / 6$ & $5 / 5$ \\
9 & $3 / 4$ & $6 / 7$ \\
10 & $3 / 3$ & $2 / 2$ \\
11 & $6 / 6$ & $6 / 6$ \\
12 & $6 / 6$ & $7 / 7$ \\
13 & $13 / 13$ & $13 / 13$ \\
\hline
\end{tabular}


alimentarse los mosquitos. Tres mosquitos cuya hemolinfa se probó al $10^{\circ}$ día post-alimentación en el hamster virémico, fueron positivos para aislamiento de virus y de estos tres mosquitos, dos se probaron como mosquito total con resultado positivo; el tercero, que había sido positivo en hemolinfa, no se probó como mosquito total. Todos los seis mosquitos probados al $11^{\circ}$ día post-infección fueron positivos para virus en hemolinfa y como mosquito total. En el $12^{\circ}$ día post-alimentación se probó la hemolinfa de 6 mosquitos y todos fueron positivos para aislamiento de virus; estos 6 mosquitos fueron también positivos para virus cuando se probaron como mosquito total. Un $7^{\circ}$ mosquito, que no se probó en hemolinfa, fue positivo como mosquito total. Finalmente, al $13^{\circ}$ día post-infección, se probaron 13 mosquitos para aislamiento de virus en hemolinfa y como mosquito total con resultado positivo.

Un mosquito de los que se alimentaron en el hamster virémico que sirvió para alimentar las hembras que se probaron para virus entre el $10^{\circ}$ y el $13^{\circ}$ día post-alimentación y que fueron congelados inmediatamente terminaron de alimentarse, fue probado para intento de aislamiento de virus y titulado en la forma ya descrita; se encontró un título de $\log 5,5$ en $0,1 \mathrm{ml}$.

Con el propósito de comparar los títulos del virus aislado en la hemolinfa y en el mosquito total, se escogieron al azar algunos de los mosquitos que habían sido positivos tanto en hemolinfa como en el mosquito total y en diferentes días post-alimentación en el hamster virémico y con ellos se hizo titulación del virus aislado. La titulación se hizo por demostración del efecto citopatogénico en células (VERO) y los resultados se muestran en el cuadro No. 2. En general, los títulos encontrados en la hemolinfa son similares a los hallados cuando se tituló el mosquito total; en 9 mosquitos los títulos fueron un poco mayores en el mosquito total que en la hemolinfa, en 5 el título en la hemolinfa fue mayor que en el mosquito total.

Los resultados de la identificación del virus en el 5,5\% de las hemolinfas, tomadas al azar, que habían producido efecto citopatogénico en células (VERO) y de los mosquitos totales positivos, probados por fijación de complemento, demostraron que el virus aislado era Encefalitis Equina Venezolana.

\section{CUADRO № 2}

Comparación de los títulos en la hemolinfa y en el mosquito total en hembras de Ps. confinnis que habian sido previamente infectadas por via oral con virus EEV (tipo enzoótico) y probadas individualmente para efecto citopatogénico en células VERO

\begin{tabular}{|c|c|c|}
\hline \multirow{2}{*}{$\begin{array}{l}\text { Días post-alimentación de } \\
\text { los mosquitos Ps. confinnis } \\
\text { en el hamster virémico. }\end{array}$} & \multicolumn{2}{|c|}{$\begin{array}{c}\text { Títulos log. DITC } 50 \text { * } \\
\text { en células VERO }\end{array}$} \\
\hline & Hemolinfa & Mosquito total \\
\hline 6 & 6.46 & 6.5 \\
\hline \multirow{2}{*}{10} & 5.31 & 7.37 \\
\hline & 5.38 & 5.50 \\
\hline \multirow{5}{*}{11} & 8.5 & 6.5 \\
\hline & 4.0 & 6.67 \\
\hline & 5.77 & 7.17 \\
\hline & 7.97 & 6.62 \\
\hline & 6.2 & 6.62 \\
\hline 12 & 6.37 & 5.50 \\
\hline \multirow{5}{*}{13} & 3.78 & 5.83 \\
\hline & 3.78 & 6.67 \\
\hline & 4.17 & 6.50 \\
\hline & 6.26 & 4.38 \\
\hline & 7.76 & 7.5 \\
\hline
\end{tabular}

* Efecto citopatogénico del $50 \%$ del tejido.

\section{DISCUSION}

Los resultados obtenidos mostraron que, similarmente a lo hallado en mosquitos Aedes aegypti inoculados intratorácicamente con virus Dengue 2, el virus de la cepa enzoótica de la EEV utilizada en este experimento se pudo detectar en la hemolinfa de mosquitos Ps. confinnis que habían sido infectados por vía oral a partir de un hamster virémico; el virus se pudo demostrar en la hemolinfa y en el mosquito total de la mayoría de los mosquitos a partir de las 24 
horas y hasta el día $13^{\circ}$ posterior a aquel en el que las hembras hicieron la comidu infectante. No se probó, para aislamiento do virus, ningún mosquito antes de las 24 horas, ni después del $13^{\circ}$ día; se hace necesario investigar en qué momento, después de realizada por el mosquito la comida infectante, es posible demostrar el virus en la hemolinfa, pues a juzgar por los resultados hasta ahora obtenidos, este hecho parece suceder muy pronto después de la llegada de la sangre virémica al estómago del mosquito. Aunque no se probó ningún mosquito para aislamiento de virus después del $13^{\circ}$ día, no hay razón para pensar que no se pueda detectar este virus en la hemolinfa en los días posteriores y quizás durante toda la vida del mosquito como sucedió con los Aedes aegypti inoculados con Dengue 2(1) y en los cuales se logró demostrar el virus en la hemolinfa hasta el día $28^{\circ}$ que fue el último día que se probaron.

Hubo una completa correlación entre el efecto citopatogénico en las células VERO inoculadas con los mosquitos positivos en hemolinfa y el efecto citopatogénico en células VERO cuando estos mismos mosquitos se probaron como mosquito total; no hubo ningún mosquito que siendo positivo para virus en hemolinfa fuera negativo cuando se probó como mosquito total y viceversa.

Un alto porcentaje de los mosquitos que se ingurgitaron en los hamster virémicos y posteriormente se probaron para virus en la hemolinfa, dieron resultado positivo puesto que del ciento por ciento de las hembras investigadas en los días 6-7-8-10-11-12- y 13 post-infección se logró aislar el virus mientras que en las probadas el primer día post-infección hubo una positividad del $66 . \%$ y en los días 2 y 9 tal positividad fue del $75 \%$. Los títulos del virus aislado en la hemolinfa y el correspondiente mosquito total son sensiblemente iguales (Cuadro No. 2), de tal manera que para efectos de la demostración del virus en el mosquito, la hemolinfa es un medio adecuado que ofrece varias ventajas como las de ser estéril, permitir conservar el mosquito para posterior confirmación de su identidad taxonómica y otros estudios virológicos; además, en episodios epidémicos y epizoóticos en los cuales se están capturan- do mosquitos para intento de aislamiento de virus, cuando se recolectan mosquitos ingurgitados con sangre, con el método de la hemolinfa no es necesario esperar para procesarlas hasta que las hembras hayan hecho la digestión, eliminando de esta manera la posibilidad de que si se aisla un agente viral de estos mosquitos recién alimentados, este virus provenga de la sangre recién ingerida y no de los tejidos del mosquito.

Ps. confinnis ha sido incriminado como vector eficiente del virus de la EEV (3) tipo epidemo-epizoótico, pero hasta donde nosotros sabemos no hay información acerca ce su capacidad de transmisión del virus de la EEV tipo enzoótico. Los resultados encontrados en este trabajo indican alguna susceptibilidad de esta especie de mosquito al virus de la EEV tipo enzoótico; aunque no se determinó el umbral de infección de los mosquitos en este experimento, creemos que la alta tasa de infección se puede atribuir al alto título de la viremia en los hamster utilizados como fuente de infección de los mosquitos, pues el umbral de infección para Ps. confinnis, por lo menos para una cepa de EEV tipo epidemo-epizoótico, ha sido determinado entre $10^{3.2}$ a $10^{3.5}$ SMICLD 50 (dosis letal para el $50 \%$ de ratones lactantes inoculados por vía intracerebral) de virus por $0,02 \mathrm{ml}$. de sangre cuando se han alimentado las hembras en caballo virémico(5) y un $28 \%$ de los mosquitos se infectaron cuando la viremia de los caballos tenía un título de $5.0-5.4 \operatorname{logs} / 0.02 \mathrm{ml}$.

\section{SUMMARY}

Experiments are reported describing the recovery of an enzootic strain of Venezuelan Equine Encephalitis virus from the haemolymph of Psorophora confinnis (Arribalzaga, 1891) mosquitoes which were previously infected by feeding them upon a viremic hamster.

The virus could be demonstrated in the haemolymph of $66,6 \%$ of the mosquitoes fed 24 hours before upon a viremic hamster; at the second and ninth day after the infection the positiveness in the haemolymph was $75 \%$ 
and at sixth, seventh, eighth, tenth, eleventh, twelfth and thirteenth day the positiveness was 100 per cent.

All the mosquitoes that were positive in the haemolymph were tested individually for virus in the mosquito body and it was found a perfect correlation between both methods. When the mosquito haemolyph was negative, the whole mosquito also showed the same result. Some positive mosquitoes were taken at random and their haemolymphs and bodies were titered to compare the virus level and there was not a significant difference between the virus concentration in the haemolymph and that of the mosquito body.

\section{BIBLIOGRAFIA}

1. Morales A, Romero $M$ y Calvache de D. Concentración del virus Dengue 2 en la hemolinfa de mosquitos Aedes aegypti inoculados intratorácicamente. Biomédica 1981; 2 (1): 17

2. Olano V A, Morales A. Colonización de una cepa de Psorophora (Grabhamia) confinis (Arribalzaga, 1981) en Colombia, Biomédica 1981; 1 (2): 12.

3. Reed L J, Muench HA. A simple method of estimating fifty per cent endpoints. Am. J. Hyg. 1938; $27: 493$.

4. Sever JL. Aplication of a microtechnique to viral serologi. cal investigations. J. Inmunol. 1962; 88: 320 .

5. Henderson B E, Chappell W A, Johnston J G Jr et al. Experimental infection of horses with three strains of venezuelan equine encephalom yelitis virus. I. Clinical and virological studies. Amer J. Epidem 1971; 93: 194. 